Journal of Economics and Behavioral Studies

Vol. 2, No. 3, pp. 92-96, Mar 2011

\title{
Exploring Exports and Economic Growth Causality in Algeria
}

\author{
Abdus Samad \\ Department of Finance and Economics, Utah Valley University, Orem \& University of Bahrain \\ abdus.samad@uvu.edu
}

\begin{abstract}
This paper investigates the causality relationship between economic growth, exports and imports in Algeria using Cointegration, Error Correction Model, and VEC Granger causality/Wald Exogeniety tests. The paper finds that economic growth in Algeria is linked to export industries and import is linked to economic growth. In other words, the growth in export sectors Granger causes economic growth which, in turn, promotes the growth of imports in Algeria. The paper suggests policy prescription that the government of Algeria should put emphasis on promoting growth and development of export industries by ensuring increased productivity in such sector.
\end{abstract}

Keywords: Exports, growth, Error correction, Granger Causality, Algeria

\section{Introduction}

In theoretical growth model, exports are considered as an engine of growth. First, exports being a component of GDP, the increase of exports directly increase GDP. An increase in exports means increase in employment in export sector industries which, in turn, increase income and GDP. Second, reallocating resources from less productive sectors to exports industry and enhancing capacity utilization exports growth promotes GDP growth (Ben-David and Loewy, 1998). Third, exports support foreign exchange earnings which, in turn, assist importing capital goods. The import of capital goods and intermediate goods stimulate domestic growth (Awokuse, 2005; Balassa, 1978a; 1988b; Buffie, 1992). The theoretical exports-led-growth (ELG) model has been hotly debated because empirical evidences of trade theory do not provide conclusive causal relation between exports and economic growth. Cross-country studies, in general, lend supports for ELG i.e. positive association between exports and economic growth (Balassa, 1988 and Moschos, 1989). Islam (1998) causality test found that export expansion led economic growth in two-third of fifteen Asian countries.

Single country study results are conflicting. Studies such as Grabowski et al (1990), Sharma et al (1991) found support in favor of exports led to economic growth (ELG). On the other hand, other studies such as Yamada (1998), Boltho (1996) and Afxentiou and Serletis (1991) found evidences in support of growth-led exports. Awokuse (2005); Giles and Williams (2000); Hatemi (2002) and Kwan and Cotsomitis (1990) found bidirectional causality between exports and economic growth. Shan and Sun (1998) found evidence of one way causality running from manufacturing to exports growth. Since empirical evidences are mixed and there is no consensus on the causal relation, this paper is motivated to investigate the relation between exports and economic growth in Algeria, one of ten MENA countries. Algeria is a good field of investigation for a number of reasons. First, unlike other MENA countries such as Morocco, Tunisia, Syria and Yemen, Algeria is an oil based country and its oil is an important component of country's exports. Second, Algeria's exports constitute $48 \%$ of its GDP in 2006 with imports 24\% of GDP. The GDP growth rate of Algeria is 3\%. Since the ratios of export to GDP are quite high, the study of interrelationship is of a great interest to many. The objective of this paper is to contribute to this debate by incorporating three distinct variables ${ }^{1}$ and exploring their interrelationship through the application of (i) Johansen co-integration VECM, and Granger Causality/ Block Exogeneith Wald test, the recent advances in time series techniques. This paper is structured as: data and methodology is provided in Section II. Section III provides empirical results and conclusions.

${ }^{1}$ Islam (1998) provided detail justification for the uses of these variables in page 416. 


\section{Data and Methodology}

Data for exports, imports and GDP are annual and obtained from the World Bank Indicators, World Bank. Variables are in natural log and in constant dollar (2000). They are:

YN= Real per capita non-export GDP. Non-export GDP is measured as Gross Domestic Product minus exports. Exports are subtracted GDP for avoiding exports biasness and the spurious correlation between exports and growth².

EX= Exports of goods and services. IM= Imports of goods and services. It is incorporated for avoiding a missing variable. It an important channel for affecting the growth of GDP through the imports of capital and intermediate goods. With these variables, the paper estimates the following simple model:

$$
Y N=f(E X, I M)
$$

This paper uses Vector Error Correction estimates and VEC Granger Causality/ Block Exogeneity Wald Tests for finding causal relation and the direction of causality. As a first step to this object, Augmented Dicky-Fuller (ADF) test, of the following regression, is performed to determine whether three series tend to exhibit deterministic and /or stochastic trend and are, therefore, non-stationary.

$$
\Delta \mathrm{X}_{\mathrm{t}}=\alpha+(\boldsymbol{\rho}-1) \mathrm{X}_{\mathrm{t}}-1+\sum \theta_{\mathrm{i}} \Delta \mathrm{X}_{\mathrm{t}-1}+\beta \mathrm{T}+\mu_{\mathrm{t}}
$$

Where $\mathrm{T}$ denotes the time trend and the failure to reject the null hypothesis of unit root $(\boldsymbol{\rho}=1)$ signifies the existence of a non-stationary process. The result of the ADF test is provided in Table 1. Second, the cointegration properties of the variables are examined using Johansen (1991 and 1995a) VAR based cointegration test. Results of Co-integration test is provided in Table 2. Third, having established that a cointegrating relationship is present among variables in level form, Vector Error Correction model which combines both short term properties of economic relationship in first difference form as well as the long term relationship in level form is estimated from the following:

$$
\begin{aligned}
& \Delta Y N t=\sum \alpha 1 i \Delta Y N t-i+\sum \beta 1 i \Delta E X t-i+\sum \Psi_{1 \mathrm{i}} \Delta \mathrm{IM}_{\mathrm{t}-\mathrm{I}}+\lambda \mathrm{ECTt}-\mathrm{i}+\varepsilon t \\
& \Delta E X t=\sum \beta 2 i \Delta E X t-i+\sum \alpha_{2 \mathrm{i}} \Delta \mathrm{YN}_{\mathrm{t}-\mathrm{i}}+\sum \Psi_{2 \mathrm{i}} \Delta \mathrm{IM}_{\mathrm{t}-\mathrm{I}}+\lambda \mathrm{ECTt}-\mathrm{i}+\varepsilon t \\
& \Delta I M t=\sum \Psi_{3 \mathrm{i}} \Delta \mathrm{IM}_{\mathrm{t}-\mathrm{I}}+\sum \beta 3 i \Delta E X t-i+\sum \alpha_{3 \mathrm{i}} \Delta \mathrm{YN}_{\mathrm{t}-\mathrm{i}}+\lambda \mathrm{ECTt}-\mathrm{i}+\varepsilon t
\end{aligned}
$$

Where Y, EX and IM are stationary processes, ECT represents one period lagged error correction term captured from the co-integrated regression from (3,4, and 5). $\alpha, \beta, \psi$, and $\lambda$ are coefficient, and $\varepsilon$ is error term. The null hypothesis that EX does not Granger cause Y is rejected not only if $\sum \beta$ and $\sum \psi$ are jointly significant but also if the coefficient of $\mathrm{ECT}_{\mathrm{t}-1}$ is significant (Miller and Russek, 2001). But in the Error Correction Model, the causality inference is obtained through the significance of $\lambda$. That is, the null hypothesis that EX does not Granger cause $\mathrm{Y}$ is rejected if $\lambda$ is statistically significant even if $\sum \beta_{\mathrm{i}}$ and $\sum \psi$ are not jointly significant. The direction of causality is also tested though the VEC Granger Causality/Wald Block Exogeneity tests. The results of error correction estimates and VEC Granger causality test are provided in Table 3.

\footnotetext{
${ }^{2}$ See Islam (1998)
} 


\section{Empirical Results and conclusion}

Table 1: Results ADF Unit Root Tests for Stationarity with Constant

\begin{tabular}{cccc}
\hline & \multicolumn{2}{c}{ Country: Algeria } & \\
Variables & Level & $\mathbf{1}^{\text {st }}$ difference & 2 $^{\text {nd }}$ difference \\
\hline YN & -1.11 & $-5.83^{*}$ & $-6.96^{*}$ \\
EX & 2.20 & $-7.98^{*}$ & $-11.84^{*}$ \\
IM & -1.20 & $-5.95^{*}$ & $-8.26^{*}$ \\
\hline
\end{tabular}

* Level of significance 1 percent

The ADF unit root test in Table 1 indicates that all three variables, YN, EX, and IM are non-stationary at level. The null hypothesis that they have unit root cannot be rejected. When the ADF test is performed to these variables in first difference, all of the variables become stationary (i.e. the null hypothesis of non-stationary is rejected) at level of significance of 1 percent.

\section{Table 2: Results of Johansen Co-integration Test for Algeria}

Included observations: 44 after adjustments

Trend assumption: Linear deterministic trend

Series: YN EX IM

Lags interval (in first differences): 1 to 1

Unrestricted Cointegration Rank Test (Trace)

\begin{tabular}{rrrrr}
\hline $\begin{array}{r}\text { Hypothesized } \\
\text { No. of CE(s) }\end{array}$ & Eigenvalue & $\begin{array}{r}\text { Trace } \\
\text { Statistic }\end{array}$ & $\begin{array}{r}\mathbf{0 . 0 5} \\
\text { Critical Value }\end{array}$ & Prob.** \\
\hline None $*$ & 0.925994 & 119.4539 & 29.79707 & 0.0000 \\
At most 1 & 0.085302 & 4.894976 & 15.49471 & 0.8199 \\
At most 2 & 0.021845 & 0.971854 & 3.841466 & 0.3242
\end{tabular}

Trace test indicates 1 cointegrating eqn(s) at the 0.05 level

* denotes rejection of the hypothesis at the 0.05 level

**MacKinnon-Haug-Michelis (1999) p-values

Unrestricted Cointegration Rank Test (Maximum Eigenvalue)

\begin{tabular}{rrrrr}
\hline $\begin{array}{r}\text { Hypothesized } \\
\text { No. of CE(s) }\end{array}$ & Eigenvalue & $\begin{array}{r}\text { Max-Eigen } \\
\text { Statistic }\end{array}$ & $\begin{array}{r}\mathbf{0 . 0 5} \\
\text { Critical Value }\end{array}$ & Prob.** \\
\hline None $*$ & 0.925994 & 114.5589 & 21.13162 & 0.0001 \\
At most 1 & 0.085302 & 3.923122 & 14.26460 & 0.8674 \\
At most 2 & 0.021845 & 0.971854 & 3.841466 & 0.3242 \\
\hline
\end{tabular}

Max-eigenvalue test indicates 1 cointegrating eqn(s) at the 0.05 level

* denotes rejection of the hypothesis at the 0.05 level

**MacKinnon-Haug-Michelis (1999) p-values

Both trace and Eigenvalue tests, in Table 2, indicate that the null hypothesis that there is no cointegration is rejected at a significant level of $5 \%$ for Algeria. The establishment of cointegration suggests that there exists long run equilibrium. 
Table 3: Result for Error Correction Models

\begin{tabular}{cccccc}
\hline Country & $\begin{array}{c}\text { Dependent } \\
\text { variable }\end{array}$ & $\begin{array}{c}\text { t-statistics for } \\
\mathbf{E C T}_{\mathbf{t}-\mathbf{1}}\end{array}$ & $\begin{array}{c}\text { F-statistics for } \\
\sum \Delta \mathbf{Y N}_{\mathbf{t}-\mathbf{i}}\end{array}$ & $\begin{array}{c}\text { F-statistics for } \\
\Sigma \Delta \mathbf{E X}_{\mathbf{t} \text {-i }}\end{array}$ & $\begin{array}{c}\text { F-statistics for } \\
\sum \Delta \mathbf{I M}_{\mathbf{t}-\mathbf{i}}\end{array}$ \\
\hline Algeria & YN & -1.72 & $4.12^{*}$ & 1.61 & 2.96 \\
& EX & -0.76 & $4.12^{*}$ & 1.61 & 2.96 \\
& IM & -1.71 & $4.12^{*}$ & 1.61 & 2.96 \\
\hline
\end{tabular}

*significant at a level of 1 percent

The significance of the Error Correction Term and F-statistics, in Table 3, indicates causal and long term relation among the variables in Algeria.

Table 4: VEC Granger Causality/Block Exogeneity Wald Test

Sample: 19602005

Included observations: 43

Dependent variable: D(LNIM)

$\begin{array}{rrrr}\text { Excluded } & \text { Chi-sq } & \text { df } & \text { Prob. } \\ \text { D(LNGDP) } & 8.588601 & 2 & 0.0136 \\ \text { D(LNEX) } & 21.82982 & 2 & 0.0000 \\ \text { All } & 23.33891 & 4 & 0.0001\end{array}$

Dependent variable: D(LNGDP)

$\begin{array}{rrrr}\text { Excluded } & \text { Chi-sq } & \text { df } & \text { Prob. } \\ \text { D(LNIM) } & 0.070577 & 2 & 0.9653 \\ \text { D(LNEX) } & 9.160849 & 2 & 0.0103 \\ \text { All } & 11.88615 & 4 & 0.0182\end{array}$

Dependent variable: D(LNEX)

\begin{tabular}{rrrr} 
Excluded & Chi-sq & df & Prob. \\
D(LNIM) & 0.670577 & 2 & 0.7151 \\
D(LNGDP) & 0.063203 & 2 & 0.9689 \\
All & 0.756012 & 4 & 0.9442 \\
\hline
\end{tabular}

VEC Granger Causality/ Block Exogeneity Wald test, in Table 4, shows Granger causality between economic growth, export and imports. Chi-sq value associated with GDP(YN) and Export (LNEX) suggests that both GDP and export Granger causes import growth (eq.1) and exports Granger causes GDP growth (eq. 2) . Thus, the causality runs from exports to economic growth and economic growth to imports (i.e. $E X \Rightarrow Y N \Rightarrow I M)$. Exports also Granger causes imports (EX $\Rightarrow \mathrm{IM})$. Development of Algerian export is a key factor for both the domestic economic growth of Algeria and the growth of imports. Algerian exports and export generating sectors provides vital inputs for the growth of Algeria's GDP and imports. The findings of this paper is consistent and lends supports to previous studies that export led to economic growth found by Balassa (1988), Moschos(1989), Islam (1998) Grabowski et al (1990), Sharma et al (1991) that exports led to economic growth (ELG)

\section{Conclusions}

This paper examines causal relation between economic growth, exports and imports using advanced econometric tests. The paper tested the series for Stationarity and found all series are non-stationary at level but stationary at first difference. The Johansen cointegration results found cointegrating relation among the series. The significance of ECT and F-statistics indicates causal and long term relation among the variables. The VEC Granger Causality found causality between economic growth, exports and imports. Exports Granger causes economic growth and imports. This paper lends support to previous findings of Balassa (1988), 
Moschos (1989), Islam (1998), Grabowski et al (1990), Sharma et al (1991) that exports led to economic growth (ELG).

The paper suggests some policy prescriptions. As economic growth of Algeria is linked to exports, the government of Algeria should lay greater emphasis on export mobilizing industries for its development. (i)The establishment and Improvement of schools, clinics, and facilities for recreations must be provided on site for the children of workers in export industries for addressing their anxiety and stress. (ii)Government must ensure a healthy and safe work environment in the work place for workforce and increased productivity. The limitation of this paper is that it is a study of a single country. So, the findings of this paper cannot be generalized for causality link nexus. Future research should include all MENA countries and more variables than this study to arrive at a generalized conclusion.

\section{References}

Afxentiou, P. C. and Serletis. A. (1991): Exports and GNP causality in the industrial countries: 1950-1985, Kyklos, 44: 67-79.

Awokuse, O. (2005): Export led growth and the Japanese economy: Evidence from VAR and acyclic graph, Applied Economic Letters, 12: 849-858.

Balassa, B. (1988): The lessons of East Asian development: an overview, Economic Development and Cultural Change, Journal of Development Economics, 36: 273-290.

Balassa, B. (1978): Export and economic growth-further evidence, Journal of Development Economics, 5 (2): 181-189.

Ben-David, D. and Loewy, M. B. (1998): Free trade growth and Convergence, Journal of Economic Growth, 3: 143-170.

Boltho, A. (1992): Was Japanese growth export led?, Oxford Economic papers, 48: 415-432.

Buffie, E. (1992): On the condition for export-led growth, Canadian Journal of Economics, 25: 211-225.

Giles, J. A. and Williams, C. L. (2000): Export-led growth: a survey of empirical literature and some noncausality results, Part 1, Journal of International Trade and Economic Development, 9: 265- 341.

Grabowski, R., Sharma, S. C. and Dhakal, D. (1990): Exports and Japanese economic development, Economic Letters, 32: 127-132.

Hatemi, J. A. (2002): Export performance and economic growth nexus in Japan: a bootstrap approach, Japan and World Economy, 14: 25-33.

Islam, N. M. (1998): Export expansion and economic growth: testing for cointegration and causality, Applied Economics, 30 (3): 415-425.

Johansen, S. (1991): Estimation and Hypothesis testing of Cointegrating vectors in Gaussian Vector Autoregessive Models, Econometrica, 59:1551-1580.

Johansen, S. (1995): Likelihood-based Inference in Cointegrated Vector Autoregressive Models, Oxford, Oxford University Press.

Kwan, A. and Cotsomitis, C. (1990): Economic growth and expanding export sector: China 1952-1958, International Economic Journal, 5:105-116.

Mashi, A. M. M. and Mashi, M. (1994): Temporal Causality Between Money and prices in LDC and the ErrorCorrection Approach: New Evidence from India, Indian Economic Review, 29 (1): 33-55.

Miller, S. M. and Russek, F. S. (2001): Co-integretion and Error Correction Models: The Temporal Causality between Government Taxes and Spending, Southern Economic Journal, 57:221-229.

Moschos, D. (1989): Export expansion, growth and the level of economic development: an empirical analysis, Journal of Development Economics, 30: 93-102.

Shan, J. and Sun, F. (1998). Export-led growth hypothesis for Australia: an empirical re-examination, Applied Economic Letters, 5:423-428.

Sharma, S. C., Norris, N. M. and Chung, D. W. (199): Exports and economic growth in industrialized countries, Applied Economics, 23: 697-707.

Yamada, H. (1998): A note on the causality between exports and productivity, Economic Letters, 61: 111-114. 